\title{
Study the effect of star anise extract and the pulp of kiwifruit on mice infected with cancer
}

\author{
Dalia I. Hemdan ${ }^{1, *}$ and Nabila Y. Mahmoud Abdulmaguid ${ }^{1,2}$ \\ ${ }^{1}$ Department of Food Science and Nutrition, Faculty of Science, Taif University, Taif-Al-Haweiah, P. O. Box 888, ZIP code 21974, Taif, KSA \\ ${ }^{2}$ Department of Nutrition and Food Science, Faculty of Home Economics, Al Azhar University, Egypt
}

\begin{abstract}
The antitumour activity of kiwifruit juice (K), star anise decoction (SA) and their mixture as nutritional treatment was studied in mice with Ehrlich ascites carcinoma (EAC). Female Swiss albino mice were treated by oral feeding with kiwifruit juice $(1 \mathrm{ml} /$ mice), star anise decoction $(1 \mathrm{ml} / \mathrm{mice})$ and their $\mathrm{mix}$ ture $(1 \mathrm{ml} / \mathrm{mice})$ for 14 consecutive days. Cisplatin drug was injected two times $(10 \mathrm{mg} / \mathrm{mice}$ i.p. $)$ on the fifth and seventh days. The results showed that kiwifruit and star anise as nutritional sources helped to bring back serum levels of AST and ALT enzymes and creatinine activities. Kiwifruit and star anise decreased tumour cell count and brought back the haematological data to near normal levels, arresting the cell cycle at normal phases.
\end{abstract}

Keywords: Cancer, cell cycle, kiwifruit, mice, star anise.

CANCER is considered as one of the most fatal diseases in the world ${ }^{1}$. It is the second cause of death worldwide, the first being cardiovascular diseases ${ }^{2}$. Clinical cancer treatment - whether surgery, chemotherapy or radiotherapy - varies appropriately based on the clinical findings ${ }^{3}$.

In 2007, the World Cancer Research Foundation reported that $35 \%$ of all cancer incidence worldwide is related to factors of lifestyle like physical activity, food and nutrition habits ${ }^{4}$. Recent studies have emphasized that consuming more spices, vegetables and fruits reduces the incidence of cancer ${ }^{5,6}$.

Vegetables and fruits are rich in various antioxidants (ascorbic acid, polyphenol, tocopherols and carotenoids). Antioxidants have beneficial effects on human health ${ }^{7}$. Phytocompounds are bioactive components in fruits. They play an important role as a protective shield for the human body against all chronic diseases ${ }^{8}$. Actinidia fruits species belong to the Actinidiaceae family. They are distributed throughout the world, especially in eastern Asia. Kiwifruit is classified as Actinidia species and has now become popular worldwide 9 . Fruits of Actinidia species are rich sources of vitamin E, flavonoids, minerals, vitamin $\mathrm{C}$ (ascorbic acid), pigments, chlorophylls and

*For correspondence. (e-mail: dalia.m@tu.edu.sa) carotenoids ${ }^{10-12}$. Kiwifruit has preventive effects against certain cancers through its antioxidant activities. Recently, kiwifruit was used for the treatment of different kinds of lung and liver cancers ${ }^{13}$.

Star anise Illicium verum Hook (Illiciaceae), is an aromatic, evergreen tree. It is found in Asian countries, mainly China and Pakistan. In 2002, the Ministry of Health of China classified I. verum as both medicine and food. This classification of $I$. verum ensures low toxicity to humans ${ }^{14}$. Padmashree et al. ${ }^{15}$ and Cheng Hong et al. ${ }^{16}$ reported that star anise - both plant and its extract - is an effective source of natural antioxidants. It contains high amounts of polyphenols such as anethole ${ }^{17}$. Compounds like phenolic acid derived from the plant have shown good effects in many anticancer and antioxidant models ${ }^{18}$.

The present study evaluates the antitumor activity of star anise (SA), kiwifruit $(\mathrm{K})$ and their mixture $(\mathrm{K}+\mathrm{SA})$ as a natural and safe source of food in reducing the risk of Ehrlich ascites carcinoma (EAC) as a tumour model in mice.

\section{Material and methods}

Mice

Female CD-1 mice (weighing 18:22 g), eight weeks of age, were used as experimental animals. The animals and ration diet were obtained from Taif University, Taif, Saudi Arabia. The Public Health Guide for the Care and Use of Laboratory Animals was followed in all animal procedures. To adapt to the laboratory conditions, the animals were kept in our laboratory for a week before starting the experiments $^{19}$.

\section{Reagents and cell lines}

Cisplatin (cis-diamminedichloroplatinum) was purchased from Sigma-Aldrich, Co, USA. The source that provided us with EAC was the National Cancer Institute at Cairo, Egypt. EAC was kept in the laboratory by transplanting females CD-1 mice in the ascitic form. Tumour cell suspensions were prepared in phosphate buffer saline (PBS) at $2 \times 10^{6}$ viable cells $/ \mathrm{ml}$ and intraperitoneal injection (i.p.) $0.25 \times 10^{6}$ tumour cells $/$ mice suspended in $0.1 \mathrm{ml}$ (ref. 20). 


\section{Preparation of plant materials}

The plant materials, viz. star anise and kiwifruit were bought from traditional markets selling herbal medicine. Five grams of star anise was put in $200 \mathrm{ml}$ of cold water. The solution was covered and brought to a boil, and simmered for 10-15 min on low heat. Then it was left to cool for 10-15 min, and was passed through a tea strainer for use. Kiwifruit was peeled and compressed directly into an electric mixer as fresh juice for daily use.

\section{Experimental design}

Animals were classified into six groups (nine mice per group). Group I mice were injected with PBS (10 mg/ mice i.p.) as negative control. Groups II-VI consisted of mice injected with EAC at a dose of $0.25 \times 10^{6}$ cells $/$ mice i.p. Group II served as positive control with EAC only. Group III served as a reference. Mice were injected with a chemical drug cisplatin (10 mg/mice i.p.), two times on the fifth and seventh days of injection of EAC in the $(0)$ day. Nutritional treatments were classified as follows: Group IV mice were treated with a single oral administration of pure kiwifruit juice $(1 \mathrm{ml} / \mathrm{mice})$ on an empty stomach daily. Group V mice were treated with a single oral administration of star anise decoction at a concentration of $2.5 \%$ ( $1 \mathrm{ml} / \mathrm{mice})$ on an empty stomach daily. Group six mice were treated with a mixture of kiwifruit juice and star anise decoction as a single oral administration ( $1 \mathrm{ml} /$ mice) on an empty stomach daily. Animals in all groups were treated for 14 consecutive days.

At the end of the experimental period, mice were fasted overnight. They were weighed and sacrificed by cephalic dislocation. Blood samples were drawn from the optic vein and separated into two parts, one in EDTA tube for $\mathrm{CBC}$ analysis and another in an Eppendorf tube which was centrifuged at $3000 \mathrm{rpm}$ for $15 \mathrm{~min}$ to obtain clear serum for biochemical analysis.

\section{Biological evaluation}

Vital organs such as liver, spleen and kidney were removed aseptically, washed with saline solution, dried using filter paper and weighed according to the method described by Drury and Wallington ${ }^{21}$. They were kept frozen at $-80^{\circ} \mathrm{C}$ for molecular and immunological analyses.

\section{Biochemical analysis}

Fresh serum was used for biochemical analysis. Aspartate aminotransferase (AST) and alanine aminotransferase (ALT) activities were determined according to the method of Reitman and Frankel ${ }^{22}$. The serum creatinine concentration was estimated by alkaline picrate method according to method of Roy and Hertha ${ }^{23}$.

\section{Complete blood count}

Whole blood samples were used to assay the total count of peripheral blood leukocytes (PBL). The total number of leukocytes in peripheral blood was enumerated using an automated instrument for CBC (VetScan HM2 ${ }^{\mathrm{TM}}$ Hematology System, Abaxis $\left.{ }^{\circledR}, \mathrm{CA}, \mathrm{USA}\right)^{24}$.

\section{EAC cells - cell account}

After the mice were sacrificed, ascetic fluid was individually withdrawn from EAC-bearing mice, both treated and untreated, using a $10 \mathrm{ml}$ plastic syringe containing $5 \mathrm{ml}$ of cold saline. EAC cells were first separated from the ascetic fluid by centrifugation at $300 \mathrm{~g}$ for $2 \mathrm{~min}$ and the supernatant was discarded. The cells were washed twice with PBS to completely remove the blood cells. Washed and packed cells were then resuspended in a fixed volume of saline. The viability of tumour cell suspensions was counted using trypan blue dye exclusion assay and a hemocytometer ${ }^{25}$.

\section{Preparation of single-cell suspension from spleen}

Sacrificed mice spleens were placed into a tissue culture dish and torn apart into a cell suspension by pressing with the plunger of a $3 \mathrm{ml}$ syringe. Cells were grouped in $10 \mathrm{ml}$ PBS and cell suspension was passed through a cell strainer to remove clumps and debris. The cell suspension was put in a conical tube. It was centrifuged for $5 \mathrm{~min}$ $(400 \mathrm{~g})$ at $4^{\circ} \mathrm{C}$ and the supernatant was discarded. The pellet was resuspended in lysis buffer $5 \mathrm{ml} /$ spleen. The cell suspension was kept at room temperature for $5 \mathrm{~min}$ with occasional shaking. The reaction was terminated by diluting the lysis buffer with $20-30 \mathrm{ml} 1 \mathrm{X}$ PBS. The cells were centrifuged $(400 \mathrm{~g})$ at $4^{\circ} \mathrm{C}$ and the pellets were resuspended in complete RPMI or PBS till cell count and viability analyses were performed ${ }^{26}$.

\section{Cell-cycle analysis}

Spleen cell suspensions were counted using a hemocytometer with trypan blue dye exclusion assay ${ }^{27,28}$. Cell suspensions were treated with PBS and fixed with 70\% ethanol on cold ice for $24 \mathrm{~h}$. Fixed cells were treated with $25 \mathrm{mg} / \mathrm{ml}$ of RNAase-A at $37^{\circ} \mathrm{C}$ for $30 \mathrm{~min}$ and then with propidium iodide $(5 \mathrm{mg} / \mathrm{ml}$, Sigma, USA) solution for $30 \mathrm{~min}$ in the dark $^{29}$. Cell-cycle analysis was performed using a flow cytometer (Becton Dicknson BD FACS Calibur, USA) equipped with a pressed air cooked low power $15 \mathrm{~mW}$ air-cooled argon laser ion beam $(488 \mathrm{~nm})$. The average number of tested nuclei per specimen was 10,000 and the number of nuclei checked was $120 /$ s. 


\section{Statistical analysis}

Data were summarized in tables as means \pm standard deviation (SD). Data were analysed using one-way test of variance (ANOVA) by LSD test; $P$ value $<0.05$ was considered significant. The data were implemented in SPSS computer program (v. 16), according to Armitage and Berry $^{30}$.

\section{Results}

\section{Biological evaluation}

Table 1 shows the relative weight of liver, spleen and kidney to body weight in mice injected with EAC and treated by CIS, K, SA and a mix of K + SA. Compared to the normal group, relative significant increase was observed in the weight of spleen $(P<0.05)$ in the EAC $+\mathrm{SA}$ group. No significant change in weight of organs was observed in any of the treatment groups.

\section{Biochemical analysis}

Table 2 showed results of liver enzymes as asparate aminotransferase (AST) (U/L) and alanine aminotransferase (ALT) $(\mathrm{U} / \mathrm{L})$ and kidney function indicator as creatinine $(\mathrm{mg} / \mathrm{dl})$ of all groups compared to EAC control group. The levels of AST and ALT enzymes and creatinine recorded a significant increase $(P<0.001)$ in the CIS group $(35.00 \pm 3.74 \mathrm{U} / \mathrm{L}, \quad 37.83 \pm 1.16 \mathrm{U} / \mathrm{L}$ and $1.55 \pm$ $0.06 \mathrm{mg} / \mathrm{dl}$ respectively) as compared to the EAC control group.

Groups treated with star anise and the $\mathrm{K}+\mathrm{SA}$ group showed significant decrease $(P<0.001)$ in the level of liver enzyme and creatinine compared to the EAC control group.

The levels of AST and ALT enzymes and creatinine showed significant decrease $(P<0.05)(P<0.001)$ in the $\mathrm{K}$ group $(15.83 \pm 1.72 \mathrm{U} / \mathrm{L}, \quad 13.83 \pm 2.31 \mathrm{U} / \mathrm{L}$ and $0.97 \pm 0.05 \mathrm{mg} / \mathrm{dl}$ respectively) compared to the EAC control group. The kiwifruit treated group showed maxi-

Table 1. Relative organ weight of normal, EAC and treated mice groups

\begin{tabular}{lccc}
\hline Group & Liver & Spleen & Kidneys \\
\hline Normal & $5.61 \pm 0.60$ & $0.50 \pm 0.06$ & $1.21 \pm 0.14$ \\
EAC control & $4.60 \pm 0.29$ & $0.43 \pm 0.24$ & $1.09 \pm 0.21$ \\
EAC + CIS & $4.60 \pm 0.88$ & $0.39 \pm 0.09$ & $1.02 \pm 0.12$ \\
EAC + K & $5.00 \pm 0.30$ & $0.41 \pm 0.13$ & $1.01 \pm 0.11$ \\
EAC + SA & $4.93 \pm 1.06$ & $0.80 \pm 0.22^{*}$ & $1.09 \pm 0.26$ \\
EAC + K + SA & $5.35 \pm 0.95$ & $0.58 \pm 0.08$ & $1.07 \pm 0.30$ \\
\hline
\end{tabular}

Data are mean $\pm \mathrm{SD}$ of nine mice. *Significant $P$ value $<0.05 \mathrm{com}$ pared to normal group with LSD post-test. EAC, Ehrlich ascitic carcinoma; CIS, Cisplatin; K, Kiwifruit and SA, Star anise. mum decrease of AST and ALT enzymes compared to other groups, while $\mathrm{K}+\mathrm{SA}$ group showed maximum decrease in creatinine compared to other groups.

\section{Haematological analysis}

Table 3 shows the results of $\mathrm{CBC}$ of CIS, K, SA and $\mathrm{K}+\mathrm{SA}$ groups compared to the EAC control group.

Treated groups of CIS and $\mathrm{K}$ showed a significant increase $(P<0.05)$ in RBCs compared to the EAC control group.

The kiwifruit treated group showed significant decrease $(P<0.001)$ in granulocytes levels (Gra), and induced a significant increase $(P<0.05)$ in platelet levels (PLT) compared to the EAC control group. White blood cells (WBCs) and lymphocyte (LYM) levels of the mix $(\mathrm{K}+\mathrm{SA})$ group showed significant decrease $(P<0.001)$ $(P<0.05)$ respectively, compared to the EAC control group.

\section{EAC cells - cell account}

The tumour cell count of mice injected with EAC i.p. $0.25 \times 10^{6}$ cells $/$ mice and treated with $\mathrm{CIS}, \mathrm{K}, \mathrm{SA}$ and $\mathrm{K}+\mathrm{SA}$ was recorded. The results illustrated that all treated groups are less than the EAC group. All treated groups induced a significant increase at $(P<0.001)$ and $(P<0.05)$ compared to CIS group (Table 4 and Figure 1$)$.

\section{Cell-cycle analysis}

Cell-cycle analysis was performed for spleen cell suspensions using a hemocytometer and trypan blue dye exclusion assay. The per cent distribution of Sub G1, G0/1, S phase $\%$ and $\mathrm{G} 2 / \mathrm{M}$ of the EAC cells before and after treatment by CIS, K, SA and $\mathrm{K}+\mathrm{SA}$ was measured. Group 2 was injected with EAC cells only. Data demonstrated to (sub G1\%), (G0/1\%), (S phase\%) and (G2/M\%)

Table 2. Liver enzymes and creatinine of normal, EAC and treated mice groups

\begin{tabular}{llcl}
\hline Groups & AST $(\mathrm{U} / \mathrm{L})$ & ALT $(\mathrm{U} / \mathrm{L})$ & Creatinine $(\mathrm{mg} / \mathrm{dl})$ \\
\hline Normal & $12.16 \pm 2.31$ & $6.00 \pm 1.41$ & $0.68 \pm 0.10$ \\
EAC control & $19.83 \pm 2.78$ & $19.50 \pm 1.64$ & $1.30 \pm 0.14$ \\
EAC + CIS & $35.00 \pm 3.74 * *$ & $37.83 \pm 1.16^{* *}$ & $1.55 \pm 0.06 * *$ \\
EAC + K & $15.83 \pm 1.72 *$ & $13.83 \pm 2.31 * *$ & $0.97 \pm 0.05 * *$ \\
EAC + SA & $16.83 \pm 1.47$ & $14.67 \pm 2.58^{* *}$ & $0.90 \pm 0.01 * *$ \\
EAC + K + SA & $19.00 \pm 1.67$ & $24.16 \pm 2.31^{* *}$ & $0.85 \pm 0.07 * *$ \\
\hline
\end{tabular}

Data are mean $\pm \mathrm{SD}$ of nine mice. * Significant $P$ value $<0.05$ and **significant $P$ value $<0.001$ compared to EAC control group with LSD post-test. EAC, Ehrlich ascitic carcinoma; CIS, Cisplatin; K, Kiwifruit and SA, Star anise; AST, Asparate aminotransferase; ALT, Alanine aminotransferase. 
Table 3. Complete blood cell count (CBC) of normal, EAC and treated mice groups

\begin{tabular}{lcccccc}
\hline Group & WBCs $\left(10^{3} / \mu \mathrm{l}\right)$ & LYM $(\%)$ & MON $(\%)$ & Gra $(\%)$ & PLT $\left(10^{5} / \mu 1\right)$ & RBCs $\left(10^{6} / \mu 1\right)$ \\
\hline Normal & $6.83 \pm 0.95$ & $41.82 \pm 2.81$ & $0.85 \pm 0.24$ & $40.68 \pm 1.31$ & $6.48 \pm 1.04$ & $7.30 \pm 0.26$ \\
EAC control & $9.97 \pm 1.79$ & $47.35 \pm 3.79$ & $1.55 \pm 0.13$ & $49.67 \pm 1.27$ & $4.73 \pm 0.67$ & $6.18 \pm 0.88$ \\
EAC + CIS & $7.03 \pm 1.61$ & $37.65 \pm 2.87$ & $1.35 \pm 0.15$ & $40.87 \pm 3.49$ & $5.12 \pm 1.06$ & $6.65 \pm 0.39 *$ \\
EAC + K & $7.57 \pm 1.73$ & $44.83 \pm 3.70$ & $1.28 \pm 0.15$ & $34.88 \pm 3.15 * *$ & $6.52 \pm 1.08^{*}$ & $7.01 \pm 0.71 *$ \\
EAC + SA & $7.43 \pm 0.54$ & $40.97 \pm 3.76$ & $1.30 \pm 0.17$ & $43.90 \pm 1.67$ & $5.66 \pm 0.84$ & $6.87 \pm 0.52$ \\
EAC + K + SA & $6.93 \pm 1.64 * *$ & $41.32 \pm 2.44 *$ & $0.77 \pm 0.12$ & $45.25 \pm 2.26$ & $5.27 \pm 0.46$ & $12.35 \pm 0.82$ \\
\hline
\end{tabular}

Data are mean $\pm \mathrm{SD}$ of nine mice. *Significant $P$ value $<0.05$ and **significant $P$ value $<0.001$ compared to EAC control group with LSD posttest. WBCs, White blood cells; LYM, Lymphocytes; PLT, Platelet; RBCs, Red blood cells; Hb, Haemoglobin.

Table 4. Tumour cell count of normal, EAC and treated mice groups

\begin{tabular}{lc}
\hline Group & Tumour cell count $\left(10^{6}\right.$ cells/mice $)$ \\
\hline EAC control & $14.87 \pm 1.57$ \\
EAC + CIS & $4.11 \pm 1.10$ \\
EAC + K & $7.57 \pm 1.56^{* *}$ \\
EAC + SA & $7.21 \pm 0.34^{* *}$ \\
EAC + K + SA & $5.73 \pm 2.84^{*}$ \\
\hline
\end{tabular}

Data are mean $\pm \mathrm{SD}$ of nine mice. *Significant $P$ value $<0.05$ and ** significant $P$ value $<0.001$ compared to EAC + CIS group with LSD post-test.

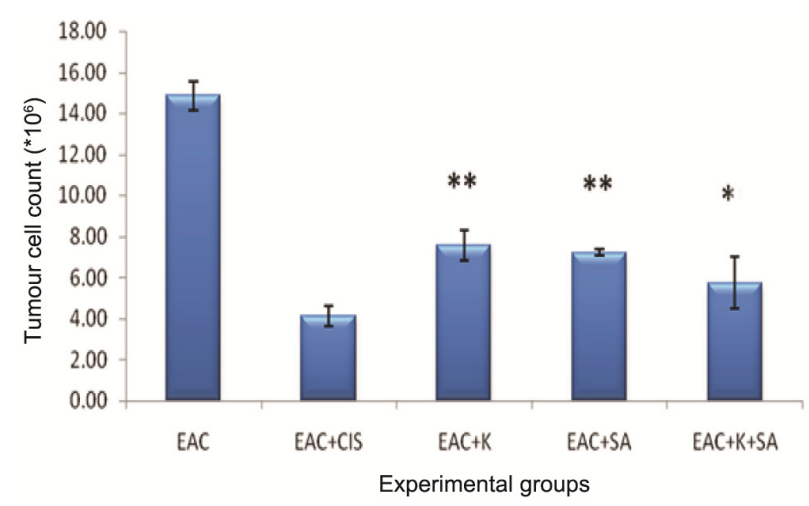

Figure 1. Tumour cell count of Ehrlich ascitic carcinoma (EAC) and treated mice groups.

as $5.6 \%, 60.1 \%, 11.9 \%$ and $21.3 \%$ respectively, as shown in Figure 2 which recorded high values compared to the normal group. While the treated groups recorded the highest percentage of sub G1\% as 15.1, 23.3, 20.6 and 37.6 respectively. On the other hand, the curve of $\mathrm{G} 0 / 1$ phase decreased as follows: $58.2 \%, 49.6 \%, 42.3 \%$ and $47.2 \%$. The $\mathrm{S}$ phase $\%$ had the lowest value in $\mathrm{K}+\mathrm{SA}$ and CIS groups $(4.4 \%$ and $5.9 \%$ respectively) and showed a gradual rise in $\mathrm{K}$ and $\mathrm{SA}$ groups $(13.3 \%$ and $16.7 \%$ respectively). Also, the mitotic phase (G2/M) obtained the same gradual in the values by recording lowest values in $\mathrm{K}+\mathrm{SA}$ and CIS groups ( $9 \%$ and $10.3 \%$ respectively), which then increased to $13.4 \%$ and $19.1 \%$ in $\mathrm{K}$ and SA groups respectively, compared to the EAC control group. These results suggest that kiwifruit, star anise and their mixture may be inhibiting the cellular proliferation of EAC cells via G0/G1 phase arrest (Figure 2).
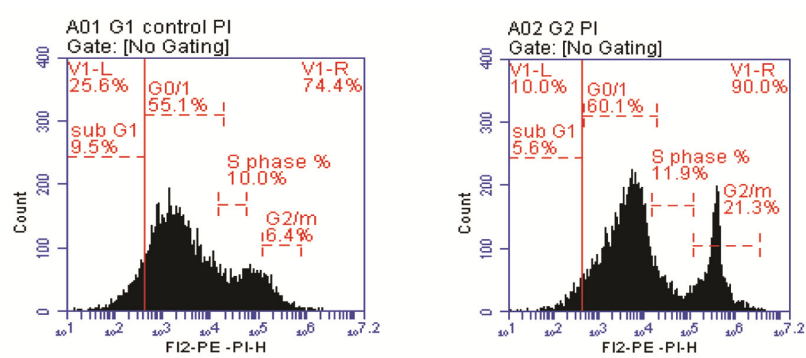

$\mathrm{A03} \mathrm{G} 3 \mathrm{PI}$
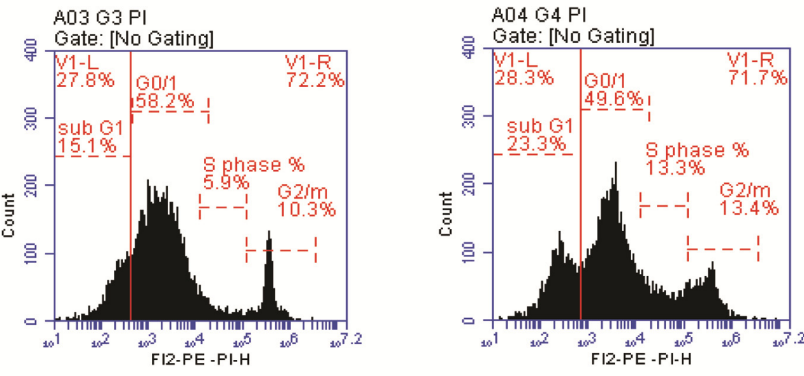

A05 G5 P
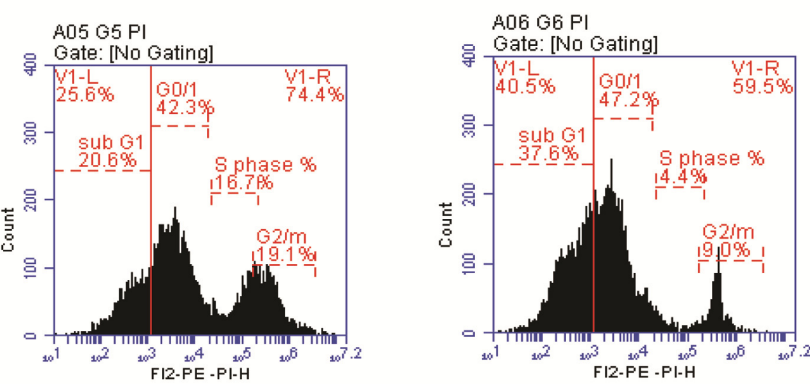

Figure 2. Spleen cell cycle phase distribution of normal, EAC and treated mice groups (sub G1 = apoptosis $\%$, G0/1 prolife, S phase $\%$ proliferation and mitosis G2/M. G1, Normal mice; G2, EAC; G3, $\mathrm{EAC}+\mathrm{CIS} ; \mathrm{G} 4, \mathrm{EAC}+\mathrm{K} ; \mathrm{G} 5, \mathrm{EAC}+\mathrm{SA} ; \mathrm{G} 6, \mathrm{EAC}+\mathrm{K}+\mathrm{SA}$.

\section{Discussion}

Liver, spleen and kidney are known to be affected by anticancer drugs ${ }^{31}$. In the treatment of a wide range of tumours, cisplatin is the most commonly used cytotoxic drug, either alone or in combination with other cytocidal agents. However, due to its detrimental adverse effects, including nephrotoxicity, its clinical uses are limited ${ }^{32}$.

In this study we evaluated the antitumor activity of kiwifruit juice, star anise decoction and their mixture on EAC tumour model. The results reveal that the relative 
organ weights of treated mice are close to normal values more than EAC and CIS groups, especially for liver and spleen relative weights. The organs with EAC and CIS groups are slightly lower than normal values in relative organs weight. On the other hand, the relative weights of spleen in SA and $\mathrm{K}+\mathrm{SA}$ treated groups were higher than the normal group.

Oral feeding of kiwifruit juice and star anise decoction after induced EAC showed the improvement of ALT and AST enzyme level compared to the EAC and CIS groups. These results indicate that ALT and AST levels are within normal limits, as biochemical parameters, which rules out hepatotoxicity.

Also, the nutritional treatment in serum creatinine level did not pick up any adverse effect on the kidney of mice groups $^{31}$. These results are in agreement with those of Attia et al. ${ }^{33}$, who reported higher levels of AST, ALT and creatinine when treated the EAC group with honeybees.

In the EAC mice group, total WBC count was elevated whereas haemoglobin and $\mathrm{RBC}$ count was reduced. These results are in agreement with those of other studies ${ }^{34,35}$. This may be because of myelopathic conditions or iron deficiency or haemolytic anemia ${ }^{36}$. However, oral administration of $\mathrm{K}$ and $\mathrm{K}+\mathrm{SA}$ induced significant increase in $\mathrm{RBC}$ count and significant decrease in WBC count respectively. This could be due to high levels of antioxidants of vitamin $\mathrm{C}$ in kiwifruit that can improve iron bioavailability ${ }^{37}$, and indicate an important function in the immune system $^{38}$.

Regarding tumour cell count results, significant increase was observed in the treated groups K, AS and $\mathrm{K}+\mathrm{AS}$, when compared to the CIS group. This finding shows that treatments have an antitumor effect against EAC cells when compared to the side effects of CIS. Despite the fact that cisplatin had better results in the treatment, it lacks selectivity for tumour tissues which leads to severe side effects ${ }^{39}$.

Stimulating the cell cycle is one of the fundamental ways to test the mechanism of action of anti-cancer drugs was used to test which the $\operatorname{drug}^{40}$. In the present study, cells of the EAC control group showed a high percentage in $\mathrm{G} 0 / 1$ phase, which revealed arrest in the cell cycle. Compared to the other treatment groups, the cells were diverse from normal phase into the apoptosis phase according to the type of treatment. The above results have been supported by Srivastava et al. ${ }^{41}$, who used quercetin which led to many cell cycle arrests in breast carcinoma cell lines. Also, our results are supported by Safarzadeh et $a l^{42}$, who found that some natural ingredients induce apoptosis pathways in cancer cells. Our results are in agreement with those of Fukumasu et al. $^{43}$ and Kabir et $a l .{ }^{44}$ who reported that many of the anti-tumour agents induce apoptosis by stopping the cell cycle in the G1 phase or S or G2/M. Collins et al. ${ }^{45}$ showed that kiwifruit extracts prevent cancer cell growth and exhibit cellular protection against oxidative DNA damage in vitro.
Dinesha et $a l .{ }^{46}$ reported that star anise extract has an effective protective ability against cell death caused by $\mathrm{H}_{2} \mathrm{O}_{2}$ and DNA from the protective activities of polyphenols, proteins and flavonoids. Oxidative stress causes many diseases, and antioxidants (natural and artificial) help prevent these diseases ${ }^{47}$. A high correlation has been shown between antioxidant activity and content of total polyphenols ${ }^{11}$. The richest sources of polyphenols are spices and herbs. Spices such as star anise have high amounts of phenolic flavours such as anethole ${ }^{17}$. Recently, a new analogy tocopherol was determined in kiwifruit $^{8}$. The studies showed that this compound participates in the overall activity of antioxidants for kiwifruits $^{48}$.

The antioxidant properties of vitamin $\mathrm{C}$ are well documented. It crushes free radicals and other types of nitrogen and reactive oxygen. Also it has the ability to regenerate other antioxidants ${ }^{38,49}$. Thus, it protects biomolecules like DNA and lipids against oxidative damage $^{50,51}$. Amongst many antioxidant species, the vitamin $\mathrm{C}$ content of kiwifruit has the greatest correlation with its total antioxidant activity ${ }^{52}$.

The chelating activities and radical scavenging antioxidant have beneficial effects against health problems associated with radicals, such as coronary heart disease and cancer ${ }^{53}$. Scientific data suggest that kiwifruit has the potential to inhibit inflammation and oxidative processes $^{54}$.

Without affecting the normal healthy cells, consumption of kiwifruit works against cancer by being cytotoxic to malignant cancer cells. Kiwifruit has been proved to contain an antimutagenic component that helps preclude the mutations of genes that can start the cancer process. The biochemical composition of kiwifruit like the plethora of antioxidants, carotenoids, vitamins and fibres is effective in the healing or prevention of cancers $^{55}$.

Methanolic extract of dried fruits of I. verum has antioxidant activity. This demonstrates its potential role in the prevention of oxidative stress ${ }^{56}$. Bharat et al. ${ }^{57}$, and Yadav and Bhatnagar ${ }^{58}$ studied the effect of star anise on the cell oxidation and showed the beneficial effects of anethole to stop carcinogenesis. Due to the high percentage of anethole, star anise extract has antioxidant activity $^{59}$.

The conducting of $\mathrm{K}, \mathrm{SA}$ and $\mathrm{K}+\mathrm{SA}$ at daily oral administrated doses preserved the relative organs weight, decreased tumour cell count and brought back the haematological analysis to near normal levels. In addition, the nutritional treatment helped to bring back serum levels of AST and ALT enzymes and creatinine activities close to the normal level. The present study recommends that daily consumption of kiwifruit juice, star anise decoction and their mixture may induce a positive effect on carcinoma patients, especially in asictic type. 


\section{Conclusion}

Thus kiwifruit juice, star anise decoction and their mixture display antitumour effect against EAC cells by arresting the cell cycle at $\mathrm{G} 0 / \mathrm{G} 1$ phase in protection against EAC cell damage. They induced enhancement in relative liver, spleen and kidney weight. Also, they brought the serum liver enzyme level (AST and ALT) activities, creatinine and haematological examination data into nearnormal levels.

1. Abdullaev, F. I., Una, R. R., Roitenburd, B. V. and Espinosa, A. J., Pattern of childhood cancer mortality in Mexico. Arch. Med. Res., 2000, 31, 526-531.

2. Babasaheb, P. B., Shrikant, S. G., Ragini, G. B., Jalinder, V. T. and Chandrahas, N. K., Synthesis and biological evaluation of simple methoxylated chalcones as anticancer, anti-inflammatory and antioxidant agents. Bioorg. Med. Chem., 2010, 18, 13641370 .

3. Samanta, S. M., Alam, M., Basu, S., Maji, T., Roy, D. K. and Jha, T., Chemotherapeutic approach to prolonged survival time in combination with immunization and glutamic acid derivatives with anti-tumor activity in tumor-bearing mice. Biol. Pharm. Bull., 2007, 30, 2334-2339.

4. Sleman, K., Mahmoud, R. and Anwar, R., Anticancer activity of anise (Pimpinella anisum L.) seed extract. Open Nutraceut. J., 2013, 6, 1-5.

5. Paola, B. et al., Nutrient dietary patterns and gastric cancer risk in Italy. Cancer Epidemiol. Biomarkers Prev., 2009, 18, 28822886.

6. Hilal, Z., Anwar, R., Omar, S. and Bashar, S., Cancer Treatment by Greco-Arab and Islamic herbal medicine. Open Nutraceut. J., 2010, 3, 203-212.

7. Wieland, P. et al., An industrial approach in the search of natural antioxidants from vegetable and fruit wastes. Food Chem., 2006, 97, $137-150$.

8. 8. Guroo, I, Wani, S., Wani, S., Ahmad, M., Mir, S. and Masoodi, F. A., Review of production and processing of kiwifruit. J. Food Proc. Technol., 2017, 8, 1-6.

9. Jiangsu New Medicine College, Dictionary of Chinese Traditional Medicines, Shanghai Science and Technology Press, Shanghai, China, 1984, 2205.

10. Ichiro, N., Yuka, Y., Miho, Y., Atsuko, S., Tetsuo, F. and Tadachika, O., Varietal difference in vitamin $\mathrm{C}$ content in the fruit of kiwifruit and other Actinidia species. J. Agric. Food Chem., 2004, 52, 5472-5475.

11. Guorong, D., Mingjun, L., Fengwang, M. and Dong, L., Antioxidant capacity and the relationship with polyphenols and vitamin $\mathrm{C}$ in Actinidia fruits. Food Chem., 2009, 113, 557-562.

12. Silvia, T., Elena D., Damiano, R., Rossano, M. and Lucia, G., Antioxidant capacity, ascorbic acid, total phenols and carotenoids changes during harvest and after storage of Hayward kiwifruit. Food Chem., 2008, 107, 282-288.

13. Collins, B., Horska, A., Hotten, P., Riddoch, C. and Collins, A., Kiwifruit protects against oxidative DNA damage in human cells in vitro. Nutr. Cancer, 2001, 39, 148-153.

14. Wei, L., Hua, R., Li, M., Huang, Y., Li, S., He, Y. and Shen, Z., Chemical composition and biological activity of star anise Illicium verum extracts against maize weevil, Sitophilus zeamais adults. J. Insect Sci., 2014, 14, 1-13.

15. Padmashree, A., Roopa, N., Semwal, A., Sharma, G., Agathian, G. and Bawa, A., Star-anise (Illicium verum) and black caraway (Carum nigrum) as natural antioxidants. Food Chem., 2007, 104, $59-66$.
16. Cheng-Hong, Y., Fang-Rong, C., Hsueh-Wei, C., Shao-Ming, W., Ming-Che, $\mathrm{H}$. and Li-Yeh, C., Investigation of the antioxidant activity of Illicium verum extracts. J. Med. Plants Res., 2012, 6, 314-324.

17. Pe'rez-Jime'nez, J., Neveu, V., Vos, F. and Scalbert, A., Identification of the 100 richest dietary sources of polyphenols: an application of the Phenol-Explorer database. Eur. J. Clin. Nutr., 2010, 64, 112-120.

18. Cai, Y., Luo, Q., Sun, M. and Corke, H., Antioxidant activity and phenolic compounds of 112 traditional Chinese medicinal plants associated with anticancer. Life Sci., 2004, 74, 2157-2184.

19. Sohair, R. F. and Khadiga, G., Establishing the first institutional animal care and use committee in Egypt. Philos., Ethics Hum. Med., 2016, 11, 1-6.

20. Lala, P. K., Santer, V. and Rahil, K. S., Spontaneous fusion between Ehrlich ascites tumor cells and host cells in vivo: kinetics of hybridization, and concurrent changes in the histocompatiblity profile of the tumor after propagation in different host strains. Eur. J. Cancer, 1980, 16, 487-510.

21. Drury, R. A. and Wallington, E. A., Carton's Histological Technique, Oxford University Press, New York, USA, 1980, 5th edn.

22. Reitman, S. and Frankel, S., A colorimetric method for the determination of serum glutamic oxaloacetic and glutamic pyruvic transaminases. Am. J. Clin. Pathol., 1957, 28, 28-56.

23. Roy, W. B. and Hertha, H. T., On the colorimetric determination of creatinine by the Jaffe reaction. J. Biol. Chem., 1945, 10, 581591.

24. Lou, Y. et al., Dendritic cells strongly boost the antitumor activity of adoptively transferred $\mathrm{T}$ cells in vivo. Cancer Res., 2004, 64, 6783-6790.

25. Kathiriya, A., Das, K., Kumar, E. P. and Mathai, K. B., Evaluation of antitumor and antioxidant activity of Oxalis corniculata Linn. against Ehrlich ascites carcinoma on mice. Iran J. Cancer Prev., $2010,3,157-165$.

26. Rubinstein, M. P., Kadima, A. N., Salem, M. L., Nguyen, C. L., Gillanders, W. E. and Cole, D. J., Systemic administration of IL15 augments the antigen-specific primary CD8+ T cell response following vaccination with peptide-pulsed dendritic cells. J. Immunol., 2002, 169, 4928-4935.

27. Lutz, M., Kukutsch N., Ogilvie A., Rossner, S., Koch, F., Romani, N. and Schuler, G., An advanced culture method for generating large quantities of highly pure dendritic cells from mouse bone marrow. J. Immunol. Methods, 1999, 223, 77-92.

28. Díaz-Montero, C. M., El Naggar, S., Al Khami, A., El Naggar, R., Montero, A. J., Cole, D. J. and Salem, M. L., Priming of naive cells in the a presence of IL-12 selectively enhances the survival of CD8+CD62 Lhi cells and results in superior anti-tumor activity in a tolerogenic murine model. Cancer Immunol. Immunother. 2008, 57, 563-572.

29. Afrah, F., Mohamed, L., Wafaa, M. and Yara, A. Nicotinic acid inducing G0/G1 cell cycle arrest and apoptosis in Ehrlich ascites carcinoma cells in vivo. Alex. J. Veter. Sci., 2017, 53, 79-87.

30. Armitage, P. and Berry, G., Statistical Methods in Meckwell, Oxford, UK, 1987, pp. 93-213.

31. Shipra, P., Arpita, S. S., Swarup, P. and Kalyan, K. M., Histological vis-à-vis biochemical assessment on the toxic level and antineoplastic efficacy of a synthetic drug Pt-ATP on experimental animal models. J. Exp. Clin. Cancer Res., 2008, 27, 1-8.

32. Abdel-Moneim, M. et al., Dimethylsulfoxide exacerbates cisplatin induced cytotoxicity in Ehrlich ascites carcinoma cells. Cancer Cell Int., 2015, 15, 1-9.

33. Attia, W., Gabry, M., El-Shaikh, K. and Othman, G., The antitumor effect of bee honey in Ehrlich ascite tumor model of mice is coincided with stimulation of the immune cells. Egypt. J. Immunol., 2008, 15, 169-183.

34. Muralidhar, A., Somasekhar, A., Sumanjali, A., Praveen, B., Lakshmi, B., Shahdul T. and Bhargavi, D., Anticancer activity of 
Tephrosia purpurea root extracts against Ehrlich ascites carcinoma (EAC) cells in Swiss albino mice. Pelagia Res. Lib., 2014, 5, 81-87.

35. Ahmed, H., Ragaa, H. Al Tahtawy, F. and Amr, M., Antitumor and antioxidant activity of honey in mice bearing Ehrlich ascites carcinoma. Acad. J. Cancer Res., 2014, 7, 208-214.

36. Fenninger, L. and Mider, G., Energy and nitrogen metabolism in cancer. In Advances in Cancer Research (eds Grenstein, J. P. and Haddow, A.), Academic Press, New York, USA, 1954, vol. 2, p. 244.

37. Beck, K., Conlon, C., Kruger, R., Coad, J. and Stonehouse, W., Gold Kiwifruit consumed with an iron-fortified breakfast cereal meal improves iron status in women with low iron stores: a 16 week randomized controlled trial. Br. J. Nutr., 2011, 105, 101109.

38. Carr, A. and Frei, B., Does vitamin $\mathrm{C}$ act as a pro-oxidant under physiological conditions? FASEB J., 1999, 13, 1007-1024.

39. Amani, F. H., Noureldeen, Hana, M., Gashlan, Nuha, A., Al-Ghamdi and Ramadan, M., In vivo antitumor activity of bis (4bromobenzaldehyde-4-iminacetophenone) tetraaquochromium (III) sulphate complex against Ehrlich ascites carcinoma cells induced in mice. Res. J. Pharma. Biol. Chem. Sci., 2017, 8, 1406-1414.

40. Déborah, R. et al., Toxicity and antitumor efficacy of Croton polyandrus oil against Ehrlich ascites carcinoma cells. Rev. Bras. Farmacogn., 2016, 26, 751-758.

41. Srivastava, S. et al., Quercetin, a natural flavonoid Interacts with DNA, arrests cell cycle and causes tumor regression by activating mitochondrial pathway of apoptosis. Sci. Rep., 2016, 6, 240-249.

42. Safarzadeh, E., Shotorbani, S. and Baradaran, B., Herbal medicine as inducers of apoptosis in cancer treatment. Adv. Pharm. Bull., 2014, 4, 421-427.

43. Fukumasu, H., Latorre, A. O. and Zaidan-Dagli, M. L., Paullinia cupana Mart. var. sorbilis, guarana, increases survival of Ehrlich ascites carcinoma (EAC) bearing mice by decreasing cyclin-D1 expression and inducing a G0/G1 cell cycle arrest in EAC cells. Phytother. Res., 2011, 25, 11-16.

44. Kabir, S. R., Nabi, M. M., Haque, A., Rokon, U. Z., Mahmud, Z. H. and Reze, M. A., Pea lectin inhibits growth of Ehrlich ascites carcinoma cells by inducing apoptosis and G2/M cell cycle arrest in vivo in mice. J. Phytomed., 2013, 20, 1288-1296.

45. Collins, A., Harrington, V., Drew, J. and Melvin, R., Nutritional modulation of DNA repair in a human intervention study. J. Carcinogen., 2003, 24, 511-515.

46. Dinesha, R., Thammannagowda, S., Shwetha, K., Prabhu, M., Madhu, C. and Leela, S., The antioxidant and DNA protectant activities of star anise (Illicium verum) aqueous extracts. J. Pharmacogn. Phytochem., 2014, 2, 98-103.
47. Subhasree, B., Baskar, R., Laxmi, R., Lijina, R. and Rajasekaran, $\mathrm{P}$., Evaluation of antioxidant potential in selected green leafy vegetables. Food Chem., 2009, 115, 1213-1220.

48. Antonio, F. et al., Tocomonoenol: a new vitamin E from kiwi ( $A c$ tinidia chinensis) fruits. Food Chem., 2009, 115, 187-192.

49. Carr, A., Bozonet, S., Pullar, J., Simcock, J. and Vissers, M., Human skeletal muscle ascorbate is highly responsive to changes in vitamin $\mathrm{C}$ intake and plasma concentrations. Am. J. Clin. Nutr., 2013, 94, 800-807.

50. Mandl, J., Szarka, A. and Banhegyi, G., Vitamin C: update on physiology and pharmacology. Br. J. Pharmacol., 2009, 157, 1097-1110.

51. German Nutrition Society (DGE), Bonn, Germany, New reference values for vitamin C intake. Ann. Nutr. Metab., 2015, 67, 13-20.

52. You, J., Chang-Sik, O., Youn-Doo, P., Seok, H., Dae-Ok, K., Ung-Jin, K. and Youn-Sup, C., Physiological components of kiwifruits with in vitro antioxidant and acetylcholinesterase inhibitory activities. Food Sci. Biotechnol., 2014, 23, 943-949.

53. Lilei, Y., Anne-Laure, N. and Trust, B., Comparison of wheat flours grown at different locations for their antioxidant properties. Food Chem., 2004, 86, 11-16.

54. David, P., Juliet, A. and Lynley, N., The nutritional and health attributes of kiwifruit: a review. Eur. J. Nutr., 2018, 57, 26592676.

55. Sachin, T., Nanher, A., Sanjay, S., Vikash, K., Kanchan, B., Subodh, K. and Mukhtar, A., Kiwifruit: health benefits and medicinal importance. Rashtriya Krishi, 2015, 10, 98-100.

56. Huma, A. et al., Protocatecheuic acid underlies the antioxidant activity exhibited by Illicium verum fruit. J. Anal. Pharm. Res., 2017, 6, 1-5.

57. Bharat, B., Ajaikumar, B., Kuzhuvelil, B., Sheeja, T., Bokyung, S. and Preetha, A., Potential of spice-derived phytochemicals for cancer prevention. Planta Med., 2008, 74, 1560-1569.

58. Yadav, A. and Bhatnagar, D., Chemo-preventive effect of star anise in $\mathrm{N}$-nitrosodiethylamine initiated and phenobarbital promoted hepatocarcinogenesis. Chem. Biol. Interact., 2007, 169, 207-214.

59. Aggarwal, B., Kunnumakkara, A., Harikumar, K., Tharakan, S., Sung, B. and Anand, P., Potential of spice-derived phytochemicals for cancer prevention. Planta Med., 2008, 74, 1560-1569.

ACKNOWLEDGEMENTS. We thank the Deanship of Scientific Research, University of Taif, Saudi Arabia for providing funds for this study [research project number 1-437-4859].

Received 12 December 2018; revised accepted 30 October 2019

doi: $10.18520 / \mathrm{cs} / \mathrm{v} 118 / \mathrm{i} 1 / 87-93$ 